\title{
Є.В. ВІБЛИЙ
}

Євгеній Валерійович Віблий, аспірант Харківського національного університету внутрішніх справ*

ORCID: 0000-0003-2818-9346

\section{СТАДІЇ ВЧИНЕННЯ ЗЛОЧИНУ В ІСТОРІЇ КРИМІНАЛЬНОГО ЗАКОНОДАВСТВА УКРАЇНИ}

Постановка проблеми. Дослідження розвитку кримінального права та законодавства дає можливість застерегти від нових помилок при застосуванні правових норм. Накопичений історичний досвід важливо враховувати сучасним дослідникам, законодавцю і практикуючим юристам.

Саме тому спірні питання про стадії вчинення злочину, які вимагають подальшого вивчення і знаходження оптимальних шляхів рішення, є актуальними в історичному контексті.

Аналіз останніх досліджень і публікацій. Історичний розвиток регулювання стадій вчинення злочину досліджували у своїх роботах провідні вчені юристи, як-от: М.І. Колос, А.Г. Манькова, К.Т. Тадєєва, А.В. Горностай, В.П. Тихий, О.І. Чистякова та ін.

Однак багато питань залишились недослідженими та вимагають подальшого наукового розвитку. Це стосується і обраної теми наукової статті.

Формулювання мети статті. Виходячи з недостатності дослідження обраної теми, мета статті полягає у визначенні становлення та історичного розвитку регулювання інституту стадій скоєння злочину.

Виклад основного матеріалу. Розвиток інститут стадій скоєння злочину в Україні має давню історію. Першою пам'яткою права, в якій можна простежити зародження даного інститут, є Руська Правда1. Даний історичний документ не містить прямого поділу злочину на стадії його вчинення. Проте, виходячи зі змісту статей, можна виділити дві стадії скоєння злочину - замах і закінчений злочин. Так замах на вчинення злочину міститься в ст. 9 Короткої редакції і відповідній їй ст. 24 Широкої редакції Руської Правди. У даних статтях йдеться про випадок, коли особа дістала меч з піхви, але не завдала удару. Закінчений злочин закріплено в ст. ст. $1,3,6,7,19,27,30,31,88,89$ та ін.

Такі джерела середньовічного права, як Судебники 1497 р. та 1550 р., не закріплювали стадій вчинення злочину.

Інститут стадій скоєння злочину отримав розвиток у Соборному уложенні 1649 року. 3 точки зору А.Г. Манькова, уложення розрізняє такі стадії злочину, як умисел, замах на злочин і вчинення злочину2 ${ }^{2}$ Відповідно до ст. 1 гл. 2 умисел вчинити злочин проти життя і здоров’я государя карається стратою («Будет кто каким умышлением учнет мыслить на государьское здоровье злое дело... и такова по сыску казнить смертию»). Також замах на злочин і вчинення злочину можна простежити і в ст. 105 гл. 10. А саме, якщо хтось у суді на кого-небудь замахнеться якою-небудь зброєю, але не вдарить, то злочинець карається биттям кийками, якщо завдасть удару і ранить, то карається биттям батогом, а якщо потерпілий помре від отриманих ран, то злочинець підлягає смертній карі.

Отже, Соборне Уложення 1649 р. розділяє покарання залежно від стадії скоєння злочину.

Кримінальне законодавство петровської епохи продовжує традиції Соборного уложення 1649 р., однак Артикул Воїнський виділяє дві стадії скоєння злочину: замах і закінчений злочин ${ }^{3}$. Замахом на злочин вважаються умисні дії (бездіяльність) особи, безпосередньо спрямовані на вчинення злочину, якщо при цьому злочин не було доведено до кінця. Більшість статей, які присвячені замаху на злочин, причини не доведення злочину до кінця або не виділяють (арт. 144), або злочин не доводиться до кінця з незалежних від особи обставин (арт. арт. 164, 185). Як вказує О.І. Чистякова, замах (початок виконання злочину) відрізнявся від закінченого злочину4. Зазвичай, вони каралися однаково (до прикладу, замах на вбивство карався однаково із закінченим злочином - арт. 164). Проте був один виняток (арт. 167) - замах на згвалтування. У даному випадку суд мав право пом'якшити міру покарання на свій розсуд (за закінчений злочин встановлювалася смертна кара).

Після періоду правління Петра І тривалий час у кримінальному праві явних змін сфері правового регулювання стадій скоєння злочину не відбувалося аж до 1845 року. Уложенням про покарання кримінальні та виправні 1845 р. було включено 13 статей, що містять норми про поняття закінченого та незакінченого злочинів (ст. 8-12, 117-121, 127-128). Статтею 8 Уложення було визначено злочин як послідовний розвиток протиправної поведінка особи, що включає кілька етапів: ««при суждении о преступлениях умышленных принимаются в уважении и различаются: один лишь чрез что-либо обнаруженный умысел, приготовление к приведению оного в действо, покушение на совершение и самое совершение преступления»5.

() Є.В. Віблий, 2019

* Yevhenii Viblyi, Postgraduate student of Kharkiv National University of Internal Affairs 
У перших нормативно-правових актах Радянської влади містилися заклики до нещадного придушення контрреволюційних виступів, в тому числі «попыток анархии со стороны пьяниц, хулиганов, контрреволюционных юнкеров, корниловцев» 6 .

У постанові ВЦВК від 5 січня 1918 р. теж вживається термін «спроба», але вже стосовно скоєння конкретного злочину: «... всякая попытка со стороны кого бы то ни было или какого бы то ни было учреждения присвоить себе те или иные функции государственной власти будет рассматриваться как контрреволюционное действие...»7.

Однак вже з середини 1918 р. термін «спроба» не зустрічається в правових актах Радянської влади, його замінюе термін «замах».

У Декретах РНК від 8 травня 1918 р. «Про хабарництво» та від 22 липня 1918 р. «Про спекуляції»8 говорилося про караність замаху на отримання або дачу хабара, на вчинення діяння, щодо спекуляції, як закінченого злочину. Таке ж формулювання містилося у постанові РНК «Про набатний дзвін» від 30 липня 1918 року. Постановою Касаційного відділу ВЦВК від 6 жовтня 1918 р., що визначала підсудність Революційних трибуналів, вперше вживається термін: «підготовча стадія».

Отже, закріплюючи кримінальну відповідальність за вчинення тих чи інших злочинів, законодавство перших років Радянської влади в деяких випадках пов'язує караність не лише з вчиненням закінченого злочину, а й із такими його стадіями, як приготування та з замахом на вчинення злочину. Що стосується замаху на злочин, то не застосовувався термін «стадія», оскільки нерідко під замахом розумівся закінчений злочин, наприклад, терористичні акти визначалися в кримінально-правових актах тих років як терористичні замахи. Караним визнавався лише замах, без будь-якого пом'якшення покарання.

До видання Керівних засад РРФСР 1919 р. суди керувалися при розгляді кримінальних справ нормами декретів, постанов, звернень та закликів, і саме в кримінальному законодавстві перших років Радянської влади були закладені принципи радянського кримінального права і його інститути. Нова влада під керівництвом партії більшовиків ліквідувала старий державний апарат і створювала радянське соціалістичне кримінальне право, виробляла нову законність та новий правопорядок.

3 перших років свого існування радянська держава використовувала інститут кримінальної відповідальності для запобігання посягань та припинення найбільш тяжких злочинів вже в момент їх зародження, тобто на етапі приготування. Отже, жорсткість і репресивна спрямованість кримінального закону виправдовувалися вимогами революційного часу, громадянської війни та воєнної інтервенції.

Прийняті 12 грудня 1919 р. «Керівні засади з кримінального права РРФСР»९ (які з часом поширили дію і на підконтрольні більшовикам території сучасної України ${ }^{10}$ ) були результатом узагальнення судово-трибунальної практики за перші роки існування Радянської держави і являли собою першу систематизацію раніше виданих правових актів ${ }^{11}$.

«Керівні засади» вперше сформулювали вихідні принципи і положення побудови загальної частини майбутнього Кримінального кодексу. Розділ IV цього нормативно-правового акта називався «Про стадії скоєння злочину» і включав чотири статті (ст. ст. 17-20), в яких вперше визначалося поняття закінченого злочину (ст. 17), замаху на злочин (ст. 18) та готування до вчинення злочину (ст. 19). Визначався порядок призначення заходів репресії за готування і замах, ст. 20 виділяла лише один критерій - ступінь небезпеки злочинця, що було характерним для того часу, і вказувала, що «стадія не впливає на міру репресії». Проте надалі термін «стадії скоєння злочину» не застосовувався в законодавстві Радянської Росії.

«Основні засади кримінального законодавства СРСР і союзних республік», прийняті 31 жовтня 1924 p. ${ }^{12}$, закріпляли обов'язок судів при виборі заходів соціального захисту керуватися не лише ступенем небезпеки особи, як це зазначалося раніше, а також ступенем здійснення злочинного наміру, тобто з урахуванням стадій вчинення злочину і близькістю настання суспільно небезпечних наслідків.

Достатньо детально стадії вчинення злочину закріплював КК УСРР, який набрав чинності 1 липня 1927 року. Так, відповідно до ст. 17 КК УСРР 1927 р. за замах на злочин суд мав призначати ті самі заходи соціальної оборони, що й за вчинений злочин, враховуючи при цьому ступінь соціальної небезпечності особи, що вчинила замах. За готування до злочину (ст. 18 КК УРСР 1927 р.) заходи соціального захисту, за загальним правилом, не передбачалися. При цьому, коли у підготовчих діях було виявлено небезпеку того злочину, до якого відбувалось готування, до винного можна було застосувати один із заходів соціального захисту13.

3 часом принципи караності готування й замаху в КК УРСР 1927 р. було змінено. Згідно зі ст. 18 нової редакції КК УРСР 1927 р. замах на якийсь злочин, а також готування до злочину тягне за собою застосування тих самих заходів соціального захисту, як і вчинений злочин. При цьому конкретний захід соціального захисту обирається судом залежно від ступеня небезпечності особи, яка зазіхала на злочин або готувалась до нього, від ступеня здійснення злочинного наміру, а також від причин, з яких злочин не було доведено до кінця ${ }^{14}$.

Згідно з Кримінальним кодексом УРСР 1960 р. цим готуванням до злочину визнавалось підшукання або пристосування засобів чи знарядь або інше умисне створення умов для вчинення злочину, замахом на злочин - умисна дія, безпосередньо спрямована на вчинення злочину, якщо при цьому злочин не було доведено до кінця з причин, що не залежали від волі винного. Покарання за готування до злочину і за замах на злочин призначається за законом, який передбачає відповідальність за даний злочин. Призначаючи покарання, суд враховує характер і ступінь суспільної небезпечності дій, вчинених винним, ступінь здійснення злочинного наміру і причини, через які злочин не було доведено до кінця 15. 
Однак Глава V «Про призначення покарання і про звільнення від покарання» Загальної частини КК УРСР 1960 р. не містила положень, які б включали спеціальні засади призначення судами покарання при незакінченому злочині.

Висновки. Таким чином, дослідивши розвиток інституту стадій скоєння, злочину можна виділити етапи його становлення.

Перший етап - період зародження даного інституту в тексті «Руської Правди» і його подальшого розвитку до часів Судебника 1497 і 1550 років. У пам'ятках права немає прямого закріплення стадій вчинення злочину, проте вказано норми, котрі дозволяють умовно виділити дві стадії: замах на злочин і закінчений злочин.

Другий етап починається з прийняття Соборного Уложення 1649 року. На даному етапі законодавцем виділяється три стадії скоєння злочину: умисел, замах, закінчений злочин. Соборне Уложення 1649 р. розрізняє покарання залежно від стадії скоєння злочину.

Третій етап - це період дії Артикулу Воїнського 1715 року. Законодавець виділяє дві стадії - замах і закінчений злочин. При цьому покарання за ту чи іншу стадію практично не відрізняються, тобто замах на злочин карався як сам злочин.

Четвертий етап охоплює період з прийняття Уложення 1845 р. до перших декретів радянської влади, що належать до 1918 року. Відбувається чітка законодавча регламентація інститутів стадій скоєння злочину; 3'являються нові, раніше не знайомі стадії; покарання диференціюється залежно від стадії скоєння злочину.

У радянський період цей інститут продовжив свій розвиток, а саме: з'являються нові стадії вчинення злочину, відбувається істотне уточнення ознак тієї чи іншої стадії.

Даний період мав характер підвищеної репресивності, однак саме в радянський період правова регламентація інституту незакінченого злочину зазнала значного розвитку.

Правове регулювання відповідальності за незакінчений злочин пройшло значний шлях розвитку, який змінювався, враховуючи суспільний устрій у державі.

Окремим етапом розвитку законодавства про відповідальність за незакінчений злочин слід вважати радянську добу.

${ }^{1}$ Русская Правда (краткая редакция); Русская Правда (пространная редакция). Российское законодательство $X$-XX веков. Москва, 1984. Т. 1. С. 47-49, 64-80.

2 Маньков А.Г. Уложение 1649 г. Кодекс феодального права России. Москва, 2003. 294 с.

3 Артикул Воинский 1715 года. Российское законодательство X-ХХ веков. Москва, 1986. Т. 4. С. 327-365.

4 Российское законодательство X-XX веков / под общ. ред. О.И. Чистякова. Москва, 1986. Т. 4. 322 с.

5 Российское законодательство X-XX веков. Москва, 1988. Т. 6. С. 174-175, 196-198.

6 Обращение Совета Народных Комиссаров к населению о победе Октябрьской Революции и о задачах на местах, от 5 ноября 1917 г. Собрание узаконений и распоряжений Правительства Российской Республики. 1917. № 2. Ст. 2.

7 Тедеев, К.Т. (Кахабер Тамазович). Стадии совершения преступления и конструкции составов : автореф. дисс. ... канд. юрид. наук наук: 12.00 .08 . Москва, 2005. 27 с.

8 Там само. С. 11

9 Руководящие начала по уголовному праву РСФСР: Постановление НКЮ от 12 декабря 1919 г. Сборник документов по истории уголовного законодательства СССР и РСФСР 1917-1952 г2. / под ред. И.Т. Голякова. Москва: Госуд. изд-во юрид. лит., $1953.372 \mathrm{c.}$

10 Колос М.І. Особливості радянської кримінально-правової політики в Україні 1917-1922 років / М.І. Колос // Часопис Національного університету «Острозька академія». Серія «Право». 2015. № 1(11).

${ }^{11}$ Советское уголовное право. Часть Общая / под ред. М.А. Тельфера, П.И. Гришаева, Б.В. Здравомыслова. Москва, 1972. $235 \mathrm{c}$.

12 Основные начала уголовного законодательства Союза ССР и союзных республик. Собрание законов и распоряжений Рабоче-крестьянского Правительства СССР. 1924 (июль-декабрь). Отдел опубликования законов Управления Делами СНК СССР. Москва, 1927. 372 с.

13 Кримінальний кодекс: Офіційне видання. Харків: Юридичне вид-во Наркомюсту УСРР, 1927. 64 с.

14 Уголовный кодекс Украинской ССР: официальный текст с изменениями на 1 февраля 1944 г. и с приложением постатейно-систематизированных материалов. Москва: Юридическое издательство НКЮ СССР, 1944. 200 с.

15 Кримінальний кодекс України від 28.12.1960 p. URL: http://zakon2.rada.gov.ua/laws/show/2001-05

\section{References:}

Russkaia Pravda (kratkaia redaktsyia); Russkaia Pravda (prostrannaia redaktsyia). Rossyiskoe zakonodatelstvo X-XX vekov. (1984). T. 1. M. [in Russian].

Mankov, A.H. (2003). Ulozhenye 1649 h. Kodeks feodalnoho prava Rossyy. M. [in Russian].

Artykul Voynskyi 1715 hoda. Rossyiskoe zakonodatelstvo X-XX vekov. (1986). T.4. M. [in Russian].

Chystiakov, O.Y. (pod obshch. red.). (1986). Rossyiskoe zakonodatelstvo X-XX vekov. T.4. M. [in Russian].

Rossyiskoe zakonodatelstvo X-XX vekov. (1988). T. 6. M. [in Russian].

«Obrashchenye Soveta Narodnikh Komyssarov k naselenyiu o pobede Oktiabrskoi Revoliutsyy y o zadachakh na mestakh», ot 5 noiabria 1917 h. (1917). Sobranye uzakonenyi y rasporiazhenyi Pravytelstva Rossyiskoi Respublyky. 1917, 2,2 [in Russian].

Holiakova, Y.T. (pod red.). (1953). Rukovodiashchye nachala po uholovnomu pravu RSFSR: Postanovlenye NKIu ot 12 dekabria 1919 h. Sbornyk dokumentov po ystoryy uholovnoho zakonodatelstva SSSR y RSFSR 1917-1952 hh. M.: Hosud. yzd-vo yuryd. lyt. [in Russian]. 
Tedeev, K.T. (2005). Stadyy sovershenyia prestuplenyia y konstruktsyy sostavov : Avtoreferat dyssertatsyy na soyskanye uchenoi stepeny kandydata yurydycheskykh nauk. 12.00.08. M. [in Russian].

Kolos, M.I. (2015). Osoblyvosti radianskoï kryminalno-pravovoï polityky v Ukraïni 1917-1922 rokiv. Chasopys Natsionalnoho universytetu «Ostrozka akademiia». Seriia «Pravo». 1(11) [in Ukrainian].

Telfer, M.A., Hryshaev, P.Y., Zdravomislov, B.V. (pod red.). (1972). Sovetskoe uholovnoe pravo. Chast Obshchaia. M. [in Russian].

Osnovnie nachala uholovnoho zakonodatelstva Soiuza SSR y soiuznikh respublyk //Sobranye zakonov y rasporiazhenyy Raboche-krestianskoho Pravytelstva SSSR. 1924 (yiul-dekabr). (1927). Otdel opublykovanyia zakonov Upravlenyia Delamy SNK SSSR. M. [in Russian].

Kryminalnyy kodeks: Ofitsiyne vydannia. (1927). Kh.: Yurydychne vydavnytstvo Narkomiustu USRR [in Ukrainian].

Uholovniy kodeks Ukraynskoy SSR: ofytsyalniy tekst s yzmenenyiamy na 1 fevralia 1944 h. y s prylozhenyem postateyno-systematyzyrovannikh materyalov. (1944). M.: Yurydycheskoe yzdatelstvo NKIu SSSR [in Russian].

Kryminalnyy kodeks Ukrainy vid 28.12.1960 r. URL: http://zakon2.rada.gov.ua/laws/show/2001-05 [in Ukrainian].

\section{Резюме}

Віблий С.В. Стадії вчинення злочину в історії кримінального законодавства України.

У статті проведено аналіз стадії вчинення злочину в історії кримінального законодавства України. Наводяться точки зору окремих авторів із досліджуваного питання, а також показано власний огляд автора на проблему.

Ключові слова: кримінальна відповідальність, стадії злочину, незакінчений злочин, приготування, замах.

\section{Резюме}

Виблый Е.В. Стадии совершения преступления в истории уголовного законодательства Украины.

В статье проведен анализ стадии совершения преступления в истории уголовного законодательства Украины. Приводятся точки зрения отдельных авторов по исследуемому вопросу, а также показан собственный взгляд автора на проблему.

Ключевые слова: уголовная ответственность, стадии преступления, неоконченное преступление, приготовление, покушение.

\section{Summary}

Yevhenii Viblyi. Stages of crime in the history of criminal Law Ukraine.

The article attempts to analyze the stages of the crime in the history of Ukraine criminal legislation. The points of view of individual authors on the issue under study are given, as well as the author's own vision of the problem is shown.

The study of the development of criminal law and legislation makes it possible to warn against new errors in the application of legal norms. The accumulated historical experience is important for modern researchers, legislators and practicing lawyers to take into account.

That is why the controversial issues about the stage of the crime, which require further study and finding the best solutions are relevant in the historical context.

Based on the insufficiency of the chosen topic, the purpose of the article is to determine the formation and historical development of the regulation of the institution of the stages of committing a crime.

Having investigated the development of the Institute of stages of committing a crime, it is possible to identify the stages of its formation.

The first stage is the period of the birth of this institution in the text of the "Russian Truth" and its further development up to the time of the Sudebnik of 1497 and 1550 years In literature there is no direct fastening of the stages of Commission of crime, however these rules, which allow a conditionally divided into two stages: attempted and completed crime.

The second stage begins with the adoption of the Cathedral Code of 1649. At this stage, the legislator identifies three stages of committing a crime-intent, attempt, completed crime. The Cathedral Code of 1649 distinguishes punishments depending on the stage of the crime.

The third stage is the period of validity Of the article of Military 1715. the Legislator distinguishes two stages-attempt and the finished crime, thus punishment for this or that stage practically do not differ, that is attempt at a crime was punished as a crime.

The fourth stage covers the period from the adoption of the Code of 1845 to the first decrees of the Soviet power, relating to 1918 . There is a clear legislative regulation of all stages of the crime; there are new-previously unknown stages; punishment is differentiated depending on the stage of the crime.

In the Soviet period, the Institute continued its development, namely: there are new stages of committing a crime, there is a significant clarification of the signs of a particular stage.

This period was characterized by increased repression, but it was during the Soviet period that the legal regulation of the institution of unfinished crime underwent significant development.

Legal regulation of responsibility for an unfinished crime has passed a significant way of development. The development of the studied Institute changed taking into account the social structure in the state.

A separate stage in the development of legislation on liability for an unfinished crime should be considered the Soviet era.

Key words: criminal liability, foreign criminal law, the stage of crime, an incomplete crime, preparation, attempt. 